Article

\title{
The Transformation of Agricultural Development towards a Sustainable Future from an Evolutionary View on the Chinese Loess Plateau: A Case Study of Fuxian County
}

\author{
Yanjun Guo ${ }^{1,2}$, Yansui Liu ${ }^{1}$, Qi Wen ${ }^{1,3, *}$ and Yurui Li ${ }^{1}$ \\ 1 Institute of Geographic Sciences and Natural Resources Research (IGSNRR), Chinese Academy of \\ Sciences, 11A Datun Road, Anwai, Beijing 100101, China; E-Mails: gyj_china@126.com (Y.G.); \\ liuys@igsnrr.ac.cn (Y.L.); liyr@igsnrr.ac.cn (Y.L.) \\ 2 University of Chinese Academy of Sciences, Beijing 100049, China \\ 3 School of Resources and Environment, Ningxia University, Yinchuan 750021, China \\ * Author to whom correspondence should be addressed; E-Mail: Wenqi@igsnrr.ac.cn; \\ Tel.: +86-10-6488-9014; Fax: +86-10-6485-7065.
}

Received: 4 March 2014; in revised form: 27 May 2014 / Accepted: 28 May 2014 /

Published: 5 June 2014

\begin{abstract}
The Loess Plateau in China receives lots of attention from around the world. The expansion of bad agricultural practices for hundreds of years aggravated the soil erosion on the Loess Plateau, however, and a lot of efforts were and are being made to reduce the serious soil erosion as well as regional poverty. Agricultural development of the Loess Plateau is still confronted with intricate challenges such as food concerns, environment concerns, and regional poverty. The strategy of development towards sustainability offers a possible and important way to face the challenges. This study tried to develop a holistic "variation-selection-replication-retention" model to analyze the transformation of agricultural development from an evolutionary view which is generally integrative. It is indicated that policies should be lively and vibrant organisms full of innovations owning to ever-changing environment in the evolutionary view. Under this analytical framework, one possible path from serious soil erosion region to region with sustainable agriculture could be recognized in the case study of Fuxian County: serious soil erosion regions $\rightarrow$ regions with poor production conditions $\rightarrow$ production-optimized regions $\rightarrow$ regions with developed agriculture $\rightarrow$ regions with sustainable agriculture. Diversified integrative development is suggested due to regional differences and the possible developing order in Fuxian County. State-subsidized "Grain for Green" policy and diversified land use are necessary for the transformation of serious soil erosion regions
\end{abstract}


which are usually trapped in regional poverty. To the transformation of regions with poor production conditions, a state-subsidized "production optimization" policy and diversified land use deserve to be considered, due to regional poverty in regions with poor production conditions. Agricultural scale operation is priority for the transformation of production-optimized regions towards agricultural modernization. Ecological thinking is very helpful for the transformation of regions with developed agriculture. The area of serious soil erosion regions in Fuxian County has dropped down from $1760 \mathrm{~km}^{2}$ in 1949 to $360.6 \mathrm{~km}^{2}$ in 2010 . The diversified integrative routine tends to be one possible way to realize the development towards sustainability.

Keywords: agricultural transformation; sustainable development; evolution; routine; Loess Plateau

\section{Introduction}

The Loess Plateau is located between $34-40^{\circ} \mathrm{N}$ and $101-138^{\circ} \mathrm{E}$ in North China, covering an area of 0.64 million $\mathrm{km}^{2}$ [1]. The Loess Plateau, as one of the most serious soil erosion areas in the world, receives a lot of attention from around the world [2-9]. It has an extremely hilly loess landscape and a semi-arid climate. It is characterized by steep sloping lands, which are unsuitable for cropping. The mean annual rainfall is mostly between 350 and $550 \mathrm{~mm}$, of which more than $70 \%$ occurs in the rainy season of June to September. Over $60 \%$ of the land in the Loess Plateau region has had severe soil erosion [2].

\subsection{The Evolution of the Loess Plateau and Agricultural Development}

About 2000 years ago, most areas were covered by forest and grassland, so little soil erosion was induced [10]. About 1400 years ago, the river water just became turbid and soil erosion increased greatly [11-13]. With the population growing, the situation worsened. Serious soil erosion on the Loess Plateau was mainly due to irrational land-use (many unsuitable areas were reclaimed for agricultural purposes) and low vegetation coverage [13,14]. In 1960s and 1970s, irrational land-use was exacerbated to some extent when the Chinese government gave priority to food production before reforming and opening-up by reclaiming more lands to relieve the pressure from population growth due to low productivity $[15,16]$. The serious soil erosion leaded to less fertile lands so that more areas needed to be reclaimed to sustain the population growth, resulting in land deterioration, regional poverty, and water scarcity [17,18]. In 1994, the World Bank partnered with the Chinese government to implement "the Loess Plateau Watershed Rehabilitation Project" on 15,600 $\mathrm{km}^{2}$ of land. This project was designed for increasing agricultural production and farmer incomes as well as decreasing soil erosion and sedimentation by re-vegetating slopes with trees or grasses, constructing check-dams, and introducing sustainable agricultural practices $[19,20]$. Meanwhile, the Chinese government implemented the "Grain for Green Project" (GFG) policy on the Loess Plateau, which has run since 1999 to deal with the serious soil erosion and ecological degradation. The ecological environment of 
Loess Plateau has been recovered to some extent and lots of steep cultivated lands were restored to vegetation [21-23]. However, it is not necessarily true that GFG will benefit all households and improve local rural living conditions [24-26]. Besides, there is an urgent concern that farmers get less and less subsidies and possibly reclaimed land if the Grain for Green Project subsidy policy weakens [27-30]. Therefore, the focus turned to the development towards sustainability. Early in 1999, the Word Bank partnered with the Chinese government to implement "Second Loess Plateau Watershed Rehabilitation Project". The second project was to help achieve development towards sustainability on the Loess Plateau by increasing agricultural production and incomes and improving ecological conditions [31]. The Sustainable Livelihoods Approach was also proposed and praised highly, for its ability to achieve development towards sustainability [32,33]. Programs such as the Natural Forest Conservation Program, Terraced Field Construction Program, and Integrated Rain-harvesting Agriculture were also initiated [34]. The way of land rehabilitation on the Loess Plateau has become more integrative so as to achieve development towards sustainability efficiently $[2,33,35]$. One project named the "Gully Land consolidation Project" (GLCP) was initially implemented in 2010 by local government aiming to develop a possible solution to the conflict between agricultural development and environment protection. GLCP originated in some counties of Yan'an city, Shaanxi province, and the middle of the Loess Plateau [36]. GLCP was to create more lands suitable for farming in gullies for more barren slope land restoration to vegetation instead. Then it was spread and brought some benefits such as saving waters, creating farmland for food security, and reducing disasters [37]. Nonetheless, it still needs to be improved due to various gullies situations [38]. In sum, the Loess Plateau had undergone a huge change from little soil erosion area to serious soil erosion area mainly due to long irrational land use, especially reclaiming lots of unsuitable lands for agricultural purposes. Fortunately, lots of progresses have been done to deal with serious water and soil loss on the Loess Plateau. Annual sediment yield of the Loess Plateau decreased from $16.0 \times 10^{8}$ ton $(1950-1969)$ to $13.2 \times 10^{8}$ ton in the $1970 \mathrm{~s}, 7.8 \times 10^{8}$ ton in the $1980 \mathrm{~s}, 7.9 \times 10^{8}$ ton in the $1990 \mathrm{~s}$, and $3.1 \times 10^{8}$ ton between 2000 and 2009 [39]. The average soil erosion rate of the Loess Plateau was $3720 \mathrm{t} /\left(\mathrm{km}^{2}\right.$ a) in 1990 [16]. Then, the average soil erosion rate had been reduced from $3362 \mathrm{t} /\left(\mathrm{km}^{2}\right.$ a) in 2000 to $2405 \mathrm{t} /\left(\mathrm{km}^{2}\right.$ a) in 2008 through GFG policy [9]. However, more integrative ways still need to be further promoted due to the complex problems on the Loess Plateau.

\subsection{Challenges for Agricultural Development on the Loess Plateau}

Sustainability is an urgent and important development strategy for emerging complex challenges such as climate changes and ecological crisis especially when it gradually evolves into "sustainability science" (SS) which recently tends to be more and more transdisciplinary [40-44]. Agricultural sustainability, as one important part of sustainability, also receives a lot of attention [45-49]. Nonetheless, agricultural sustainability is confronted with challenges such as hunger concerns, health concerns, and environmental concerns [50]. Agricultural sustainability is especially important for the Loess Plateau, due to its urgent challenges which will undermine agricultural development on the Loess Plateau and then lead to regional poverty and environmental damages. One big challenge comes from food consumption and revenue demand which the population growth brings. Under the pressure of population growth, unsuitable sloping fields may be reclaimed for farmland and mineral resources 
may be exploited for more revenue, resulting in serious soil erosion and environmental damages [51]. Another emerging challenge is agricultural pollution induced by industry agriculture or other industries [52-55]. Extreme climate events caused by global changes are also an important challenge which can induce catastrophic damage to nature and human society [56-58]. Complex tangled challenges make it difficult to analyze just one by one without a holistic perspective. So it is necessary to explore one possible integrative way to balance agricultural development and environment protection, eventually, towards sustainable agriculture.

This paper makes both theoretical and empirical contributions: (a) as the development of agriculture on the Loess Plateau becomes more and more integrative, one holistic theoretical analytical framework is especially needed. It is helpful to borrow some ideas from evolutionary perspective which is considered to be synthesized and evolutionary; (b) to present a rich description of how the agricultural production evolved in Fuxian County under the evolutionary perspective. Then, several modes of agricultural development hidden in the process are figured out and then comparative analysis is given to identify pros and cons of each development mode; (c) based on experiences gained from all the modes, one possible integrative way to realize sustainable agriculture is discussed. Special attention is paid to regional differences that induce more diversified development.

\section{An Evolutionary Framework for the Analysis of Agricultural Development}

In the past few years, there has been a renewed interest in viewing economics as a dynamic process that is intrinsically evolutionary since Nelson and Winter [59], with the mutual borrowing of ideas between economics and biology [60] as well as from physics [61]. The evolutionary perspective on economics as a major force is providing the main counterview to the mechanistic metaphor of neoclassical economics [62] and is suggested to be a more realistic and useful way than mainstream economic thinking $[63,64]$. The importance of understanding emergence has been raised further [65]. Evolutionary thinking and modeling can contribute to the emerging research on sustainability transformations and their management with a more precise and complete way [66], which is possibly right for analyzing the agricultural development on the Loess Plateau. In the various branches of evolutionary perspective, the economic self-organization approach offers an analytical framework which can embrace a range of other positions $[67,68]$ and seem well equipped to underpin sustainable innovation policies [69]. Thus, evolutionary perspectives will also be useful for the transformation of agricultural development towards a sustainable future. A four-step (variation-selection-replication-retention) evolutionary model has been developed and adopted [70-72]. The key feature in the evolutionary perspective is the concept of routine. Routines are sequential interactions between organizational members to coordinate activities [59]. Furthermore, routines can be described as stable patterns of behavior that characterize organizational reactions to variegated, internal or external stimuli [71]. Routines have succeeded in understanding drivers of endogenous organizational change and their impact on the organization [73]. In fact, agricultural production is also conducted by lots of enterprises such as agricultural communities, agricultural firms, and self-employed smallholders, hence agricultural development can also be considered as an economic evolution. So the study tried to develop an evolutionary framework for analyzing the transformation of agricultural development in an evolutionary perspective. 
The perspective on the agricultural development transformation is summarized in Table 1 . In the transformation of agricultural development, the four steps in the evolutionary process were conceptualized as one cycle of a routine of agricultural production. The agricultural production repeated this cycle each time and routines would be changed to be adaptive to both physical environment and socioeconomic environment. The outdated routines were replaced by the new ones gradually. Transformation through the cycle over time had special characteristics due to special government-led management in China [74,75]. Moreover, the interaction mechanism of agricultural evolution could be interpreted by an evolutionary analytical framework (shown in Figure 1).

Table 1. Evolutionary framework for the transformation of agricultural development.

\begin{tabular}{cl}
\hline Framework structure & \multicolumn{1}{c}{ The evolution of agricultural production } \\
\hline Object & Physical environment, socioeconomic environment. \\
\hline Logic of variation & $\begin{array}{l}\text { Environmental changes induce adaptation of existing routines. New } \\
\text { practices emerge with the context changing based on prior } \\
\text { experiences and new acquired knowledge. }\end{array}$ \\
\hline Logic of selection & $\begin{array}{l}\text { Progressive elimination and selection of outdated and new routines } \\
\text { by both physical environment and socioeconomic environment. }\end{array}$ \\
\hline Logic of replication & $\begin{array}{l}\text { New practices can be replicated due to its advantages and more new } \\
\text { practices may occur in spatially diverse context. }\end{array}$ \\
\hline Logic of retention & $\begin{array}{l}\text { Retention for 'best practices' as relational patterns. Routines may be } \\
\text { sped up due to its applicability. }\end{array}$ \\
\hline
\end{tabular}

Source: Categories in the first column were adapted from Hatani and McGaughey [76].

Figure 1. The evolutionary analytical framework for the transformation of agricultural development.

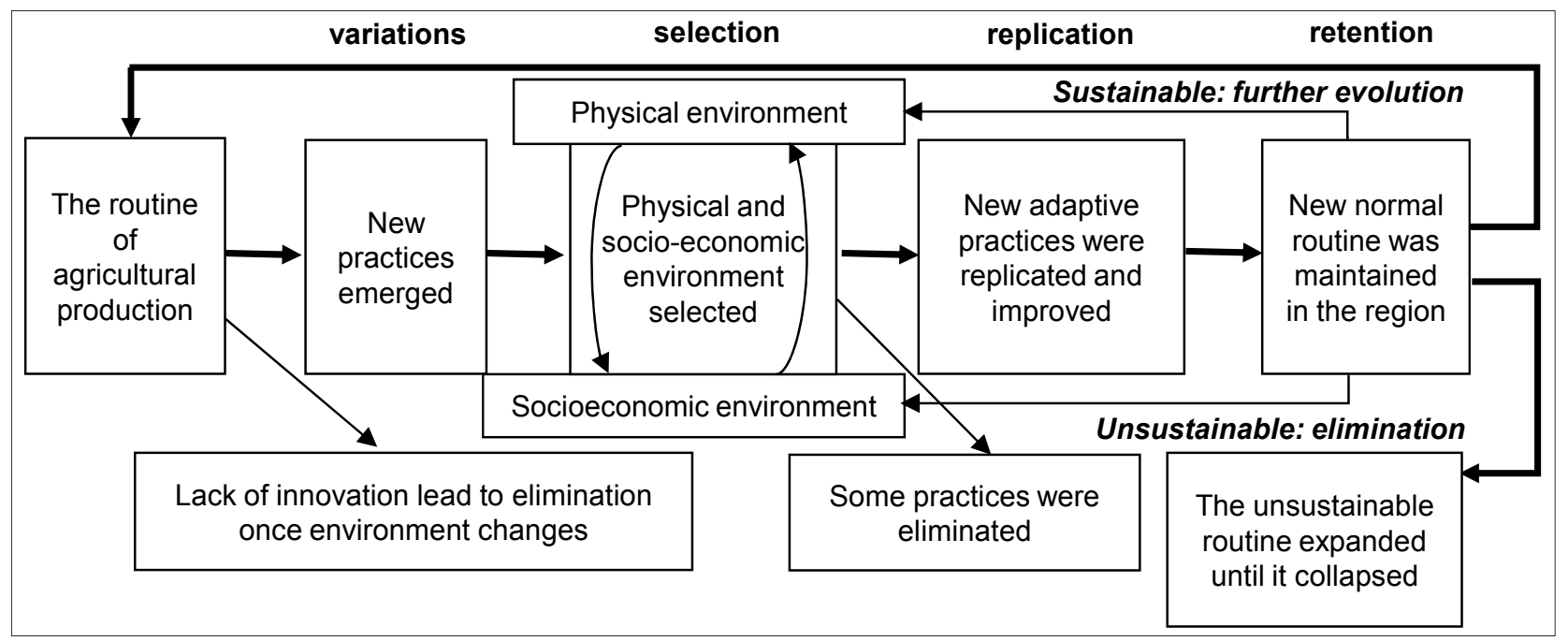

Due to the motivation for more revenue, lots of efforts were made and new practices emerged (see "variations" in Figure 1). The feasible practices were selected by both physical and socioeconomic environment and the other practices would be gradually eliminated. Physical selection pressure mainly included conditions for agricultural production (e.g., topography, soil fertility, irrigation facilities) while socioeconomic selection pressure laid in competitiveness from market, and government policy (see "selection" in Figure 1). New adaptive practices were replicated rapidly and improved (see 
"replication" in Figure 1). When these adaptive practices were spread and accepted, a new normal routine was gradually formed and usually established by policies or regulations. Once the new normal routine formed, it also had feedback effects on environment, which would induce environmental changes (see "retention" in Figure 1). Then, another selection may emerge again. If the routine of agricultural production refused to make adaptive changes to environment, it would be eliminated due to lack of innovations. Some unsustainable routines would be eliminated unexpectedly until they expanded at last. If one routine wanted to continue, it should make itself to the environment changes. It is indicated that policies should be lively and vibrant organisms full of innovations owning to ever-changing environment in the evolutionary view.

\section{Methods}

\subsection{Background of Fuxian County}

Fuxian County is located between $108^{\circ} 29^{\prime} 30^{\prime \prime} \mathrm{E}-109^{\circ} 42^{\prime} 54^{\prime \prime} \mathrm{E}, 35^{\circ} 44^{\prime} 6^{\prime \prime} \mathrm{N}-36^{\circ} 23^{\prime} 23^{\prime \prime} \mathrm{N}$, in the middle of the Chinese Loess Plateau, a part of the mid-latitude semi-arid region. It is about $111 \mathrm{~km}$ from East to west, and about $73.7 \mathrm{~km}$ from north to south, with a total area of $4181.57 \mathrm{~km}^{2}$. The annual average temperature, annual sunshine hours, average frost-free period, and average annual rainfall is 7.1-9.0 ${ }^{\circ} \mathrm{C}, 2032-2428 \mathrm{~h}, 130$ days, 500-600 mm respectively. Fuxian County's precipitation has a high-intensive intermittent characteristic, which mostly occurs in the rainy season of June to September. Fuxian County's landform mainly contains loess hilly regions, loess gully regions and low mountain regions, and the altitude ranges from 840 to $1680 \mathrm{~m}$. Loessial soil is the primary farming soil type [77].

\subsection{Research Design}

To explore the evolution of agricultural production in Fuxian County, the study adopted longitudinal case research. The periodic update of longitudinal case analysis provided important insights into analysis. Meanwhile, an evolutionary perspective was advocated to reveal the dynamic mechanism for the evolution of agricultural production, which seemed more synthesized with all possible factors included. The study argued that the transformation of agricultural production was in the variation-selection-replication-retention way, eventually, a new routine would be formed.

The study proceeded as follows: (1) to collect existing information concerning the histories of agricultural production in Fuxian County, and then, based on these data, to investigate the historical development of agricultural production in Fuxian County. Data collection was initiated in the 1950s, firstly through surveying Fuxian County's government websites and existing literatures available in China. Subsequently, more detailed data were obtained in investigations, some of which came from local government. The study also had conducted in-depth interviews with local peasants, agricultural firms, and some local government agencies. The field investigation mainly involved in Jizixian town, Niuwu town, Sixian town, and Zhiluo town; (2) to arrange data in chronological order and divide phrases of agricultural development in Fuxian County. Based on gained data, agricultural development of Fuxian County in every phrase was analyzed. Then, routines hidden in every phrase were identified and analyzed under the evolutionary framework. The study took a comprehensive consideration for possible factors, both physical and socioeconomic environment. Pros and cons of each routine were 
also identified; (3) to summarize all the agricultural production routines in Fuxian County and explore a possible efficient and sustainable agricultural production routine. Regional differences made agricultural production routines diversified spatially. Thus, regional differences were paid more attention in the possible efficient and sustainable way.

\section{Results and Discussion}

\subsection{Phrases of Agricultural Development in Fuxian County}

Based on gained data about Fuxian County, the evolutionary history of Fuxian County's agricultural development can be divided into four phases as shown in Table 2 according to both physical and socioeconomic environment. More details can be seen from Figure 2 and Table 3. Figure 2 shows the trends of agricultural development in Fuxian County from 1949 until now. Table 3 gives concrete index changes about agricultural development in Fuxian County.

Table 2. The evolution of agricultural development in Fuxian County.

\begin{tabular}{|c|c|c|}
\hline Phase & Physical environment & Socioeconomic environment \\
\hline $\begin{array}{l}\text { Phase } 1 \\
\text { 1949-1977 }\end{array}$ & $\begin{array}{l}\text { Serious soil erosion; } \\
\text { Large area }\end{array}$ & $\begin{array}{l}\text { priority for food; } \\
\text { collective production; } \\
\text { increasing population; } \\
\text { poor local government revenue; } \\
\text { poor central government revenue; } \\
\text { low productivity }\end{array}$ \\
\hline $\begin{array}{l}\text { Phase } 2 \\
1978-1998\end{array}$ & $\begin{array}{l}\text { Serious soil erosion; } \\
\text { Large area; } \\
\text { Improving in part }\end{array}$ & $\begin{array}{l}\text { priority for revenue; } \\
\text { household responsibility system; } \\
\text { large population; } \\
\text { low local government revenue; } \\
\text { sufficient central government revenue; } \\
\text { improving productivity }\end{array}$ \\
\hline $\begin{array}{l}\text { Phase } 3 \\
1999-2010\end{array}$ & $\begin{array}{l}\text { Serious soil erosion; } \\
\text { Large area; } \\
\text { Improving in part }\end{array}$ & $\begin{array}{l}\text { priority for composite benefits; } \\
\text { household responsibility system; } \\
\text { large population; } \\
\text { low local government revenue; } \\
\text { ample central government revenue; } \\
\text { improved productivity }\end{array}$ \\
\hline $\begin{array}{l}\text { Phase } 4 \\
\text { 2011-now }\end{array}$ & $\begin{array}{l}\text { soil erosion reducing; } \\
\text { small area; } \\
\text { Improving obviously }\end{array}$ & $\begin{array}{l}\text { priority for composite benefits; } \\
\text { household responsibility system; } \\
\text { large population; } \\
\text { subsidies declining; } \\
\text { increasing local government revenue; } \\
\text { ample central government revenue; } \\
\text { relatively high productivity }\end{array}$ \\
\hline
\end{tabular}


Figure 2.the trends of agricultural development in Fuxian County. (a) the scatter map of annual local government revenue and population; (b) the scatter map of land productivity and labor productivity; (c) the scatter map of land grain total output and no-grain planting percentage; (d) the scatter map of grain planting area, sown area for crops, and cultivated land area.

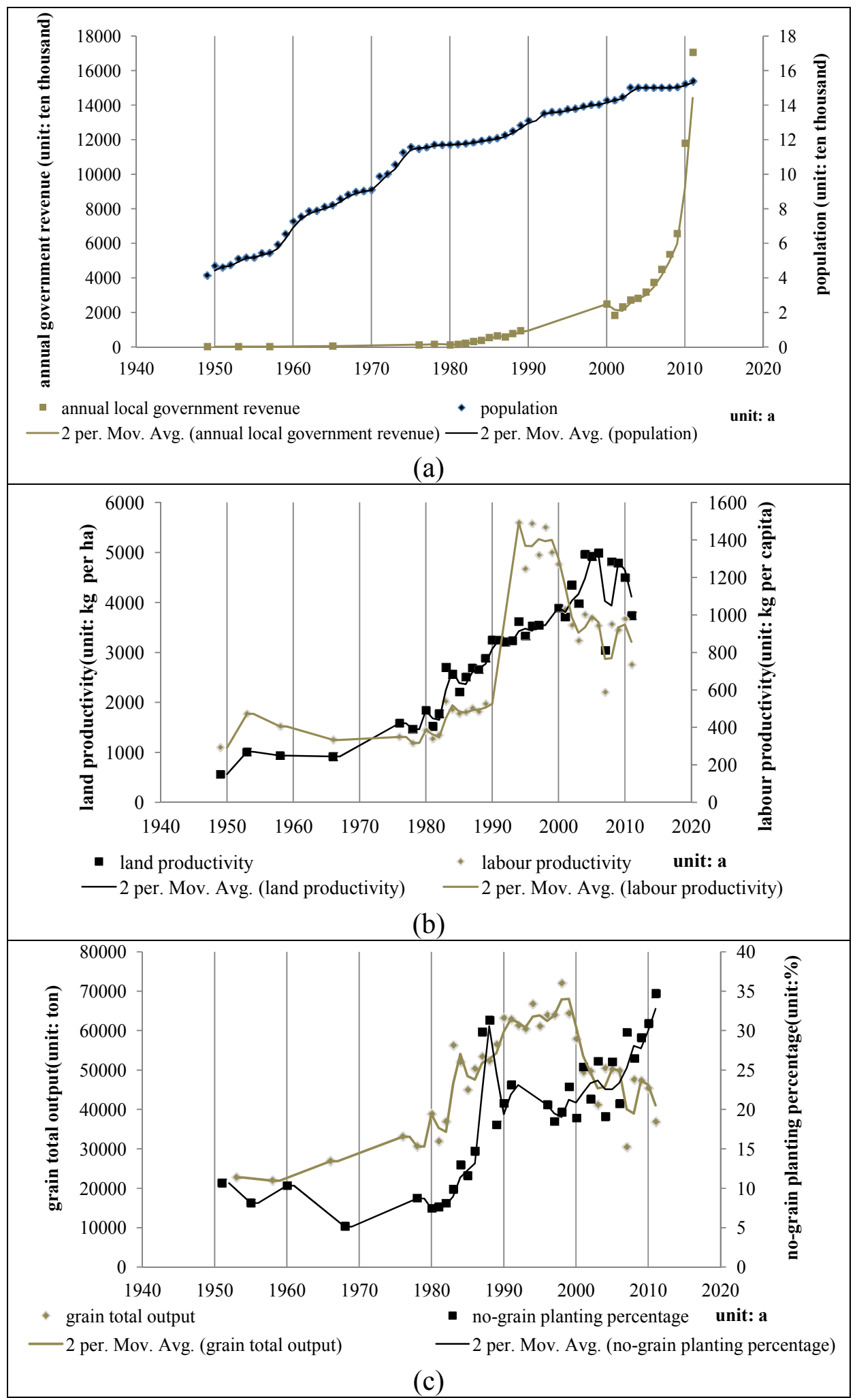


Figure 2. Cont.



Data resources: Local chronicles of Fuxian County, 1994 [78]; Yan'an City Statistical Yearbook (1993-2012).

Table 3. The index changes of agricultural development in Fuxian County.

\begin{tabular}{cccccccc}
\hline Index item & $\mathbf{1 9 4 9}$ & $\mathbf{1 9 5 8}$ & $\mathbf{1 9 6 6}$ & $\mathbf{1 9 7 6}$ & $\mathbf{1 9 8 9}$ & $\mathbf{2 0 0 0}$ & $\mathbf{2 0 1 0}$ \\
\hline Population (ten thousand) & 4.14 & 5.92 & 8.56 & 11.48 & 12.82 & 14.26 & 15.22 \\
Local government revenue (ten thousand) & 17 & 24 & 58 & 137 & 942 & 2485 & 17051 \\
Land productivity (kg per ha) & 565 & 937 & 917 & 1583 & 2888 & 3897 & 4499 \\
Labor productivity (kg per capita) & 292 & 405 & 334 & 349 & 526 & 1270 & 978 \\
Grain total output (ton) & 11,985 & 21,900 & 26,865 & 33,077 & 56,410 & 57,802 & 45,300 \\
Agricultural machinery (unit) & 0 & 3 & 6 & 625 & 2692 & 8100 & 8204 \\
No-grain planting percentage (\%) & 11 & 10 & 5 & 9 & 23 & 21 & 37 \\
Multiple cropping index (\%) & 112 & 104 & 109 & 110 & 120 & 131 & 109 \\
Sown area for crops (ha) & 23,780 & 24,333 & 31,933 & 22,733 & 23,407 & 19,358 & 10,953 \\
Grain planting area (ha) & 21,247 & 21,820 & 30,293 & 20,753 & 18,000 & 15,240 & 6915 \\
Cultivated land area (ha) & 21,227 & 23,380 & 29,307 & 20,893 & 19,533 & 14,833 & 10,069 \\
\hline
\end{tabular}

Note: Land productivity $=$ grain total output/grain planting area; labor productivity $=$ grain toal output/agricultural labor amount; no-grain planting percentage $=(1-$ grain planting area/sown area for crops $)$ $* 100$; multiple cropping index $=($ sown area for crops/cultivated land area) $* 100$. Data resources: Local chronicles of Fuxian County, 1994 [78]; Yan'an City Statistical Yearbook (1993-2012).

\subsubsection{Reorganization and Collectivization}

Phase 1 was a period of reorganization and collectivization from the foundation of New China to the Reform and Opening up (1949-1977). According to data from Local chronicles of Fuxian County, the area of serious water and soil loss covered $1760 \mathrm{~km}^{2}$, accounting for $42.1 \%$ of the whole county area, when New China was found in 1949. Through the short reorganization after World War II, due to the lack of means of production, "Mutual Aid Teams", "Agricultural Production Cooperatives", and "People's Commune" had been advocated successively by government to realize agricultural 
collectivization. Lands were owned and used by commune while agricultural production was organized by commune. Net earnings were distributed on a per capita basis rather than according to one's contribution in labor, which arouse peasants' discontent. Food security was the priority in this period and even one policy called "Food for the program" was released in 1958 due to the pressure of increasing population. In this period, the population was growing rapidly from about 1950 to about 1980 and local government revenue was low (Figure 2a). The population was just 4.14 ten thousand in 1949, and then, ascended to 11.48 ten thousand in 1976 (Table 3). The central government revenue was also low at this time [79]. The productivity of agricultural production was kept at a low level (Figure 2b) and the land productivity was just $565 \mathrm{~kg}$ per ha in 1949 (see Table 3). The grain total output seemly stalled before about 1960 and grew slowly from about 1958 when "Food for the program" policy was released in 1958 (Figure 2c) while The grain planting area, sown area for crops, and cultivated land area grew rapidly from about 1958 (Figure 2d), which implicates that the slow increase of the grain total output were attributed to the expansion of the grain planting area, sown area for crops, cultivated land area. According to Local chronicles of Fuxian County, lots of unsuitable slope lands were reclaimed, resulting in more serious environmental damage and soil erosion. The grain planting area, sown area for crops, and cultivated land area dropped down during the Culture Revolution (1966-1976) and agricultural production rapid expansion was interrupted due to disorder during the Culture Revolution (Figure 2d).

In this period, due to low productivity, and under the pressure of growing population, reclaiming more lands for food and monoculture development, were selected by the "Food for the program" policy (Figure 3). In this routine, more unsuitable slope land was reclaimed and suffered readily from soil erosion. This routine made a little effort for the growth of grain total output, but it induced a vicious circle, more unsuitable slope land-less vegetation coverage - more soil and water loss-less fertile soil-low productivity-less yields - more unsuitable slope land, which aggravated soil and water loss. However, the routine would be eliminated at last until it collapsed as mentioned in Figure 1. In fact, the routine had been adjusted soon and lasted until about 1966 as the grain planting area, sown area for crops, and cultivated land area reached the peak point, 30,293 ha, 31,933 ha, and 29,307 ha. No-grain planting percentage at this time was lowest, just 5\%. It is indicated that "Food for the program" policy released in 1958 had a great effect on the agricultural development. Due to the serious soil erosion, "Food for the program" had been adjusted as the grain planting area, sown area for crops, and cultivated land area dropped down rapidly since about 1966. 
Figure 3. The evolutionary framework of agricultural development transformation in phrase 1 .

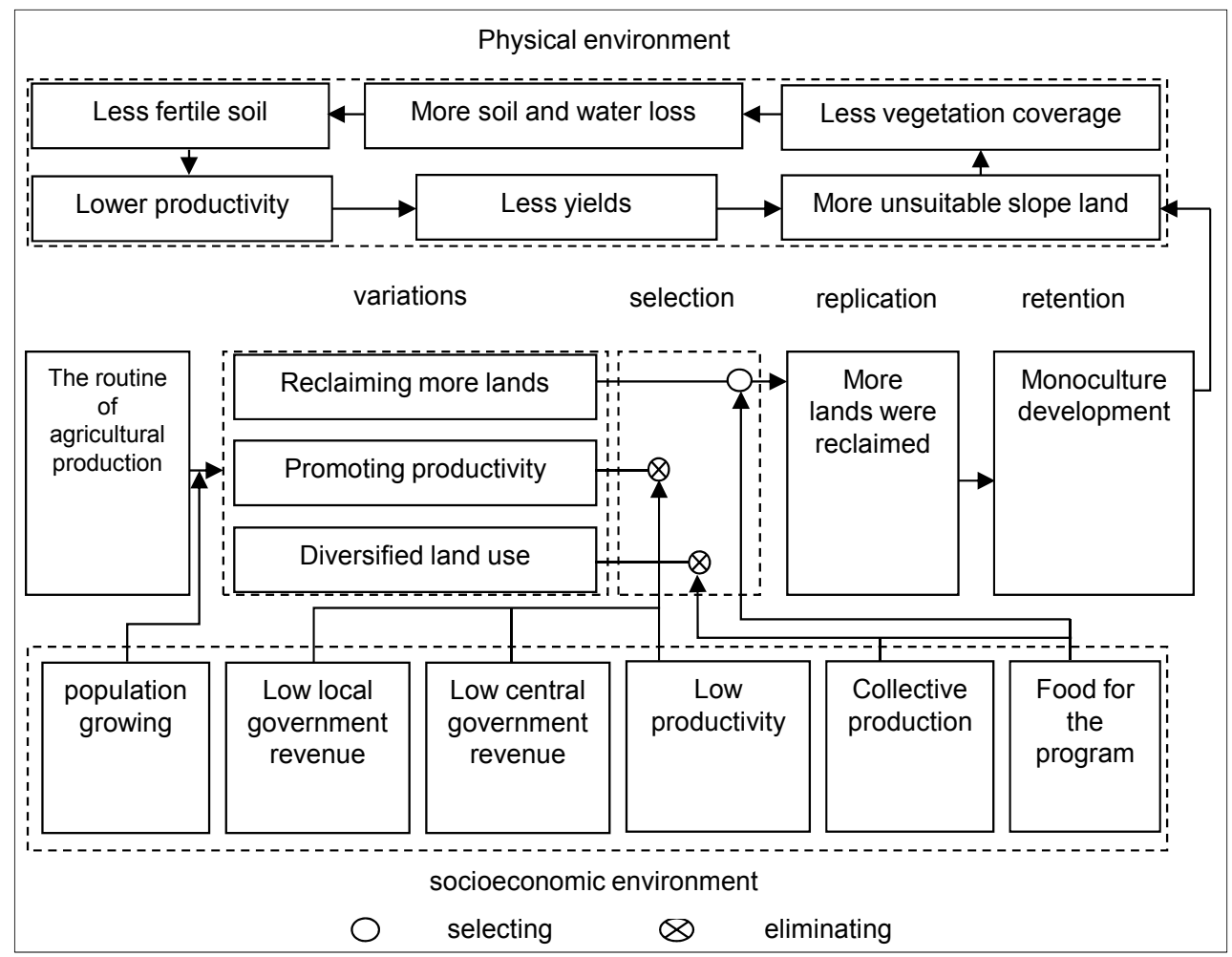

\subsubsection{Reform and Opening up}

Phase 2 started along with the Reform and Opening up. According to data from local chronicles of Fuxian County, the hash physical environment was improved slowly and serious soil erosion area in 1983 still covered $1507.3 \mathrm{~km}^{2}, 36.02 \%$ of the whole county area. The new agricultural policy "household responsibility system" was conducted in 1979 by the Chinese central government and the county government implemented the "dual farmland use" policy in 1984. Lands were distributed to each household and contracted by each household. "Dual farmland use" was that the lands contracted by each household were divided into two parts, one part was used for food production, for which each household should pay 45-75 yuan per ha every year except agricultural tax, and the other one was used for agricultural byproducts production, for which each household should pay 90-150 yuan per ha every year except agricultural tax. Then, the "dual farmland use" policy turned to be "triple farmland use" policy and the third part was more flexibly used. Household responsibility system allowed peasants to operate theirs contracted lands relatively flexibly. Diversified land use for more revenue was allowed and high-value crops such as tobacco, apples, and other cash crops were planted rapidly. In this period, the population still grew slowly and reached 12.82 ten thousand in 1989 (Table 3). Local government revenue was still low from about 1978 to about 1998 (Figure 2a) and grew to 942 ten thousand in 1989 (Table 3). Nonetheless, Chinese economy grew rapidly during this time and central government revenue increased greatly [79]. Meanwhile, the productivity of agricultural production was promoted greatly from about 1978 to about 1998 (Figure 2b). The grain total output and no-grain percentage also ran up rapidly (Figure 2c) while the grain planting area, sown area for crops, and cultivated land area decreased slowly from about 1978 to about 1998 (Figure 2d), which means that the growth of the grain 
total output were not attributed to the expansion of the grain planting area, sown area for crops, cultivated land but to the improvement of productivity.

In this period, due to improving productivity, food demand was met, then, diversified land use for more revenue was the priority (Figure 4). Reclaiming more lands for food had been eliminated due to the damages it caused. Instead, diversified routine for more revenue was selected. It was helpful to reduce soil erosion [12] mainly by transferring peasants' attention from expanding the lands to raising the productivity and revenue. Lots of peasants were also involved in non-agricultural industries. However, planting high-value crops needed money and skills. Thus, regional poverty made it difficult to conduct diversified land use and diversified development was just implemented in some rich areas. Meanwhile, the restoration funded by private in small watershed was allowed since Reform and Opening up. The involvement of rich farmers promoted the restoration to reduce soil erosion considerably according to local chronicles of Fuxian County. Farming measures, biology measures, and engineering measures were coordinated in this restoration during this period. Nonetheless, the restoration funded by private wasn't spread widely due to regional poverty.

Figure 4. The evolutionary framework of agricultural development transformation in phrase 2.

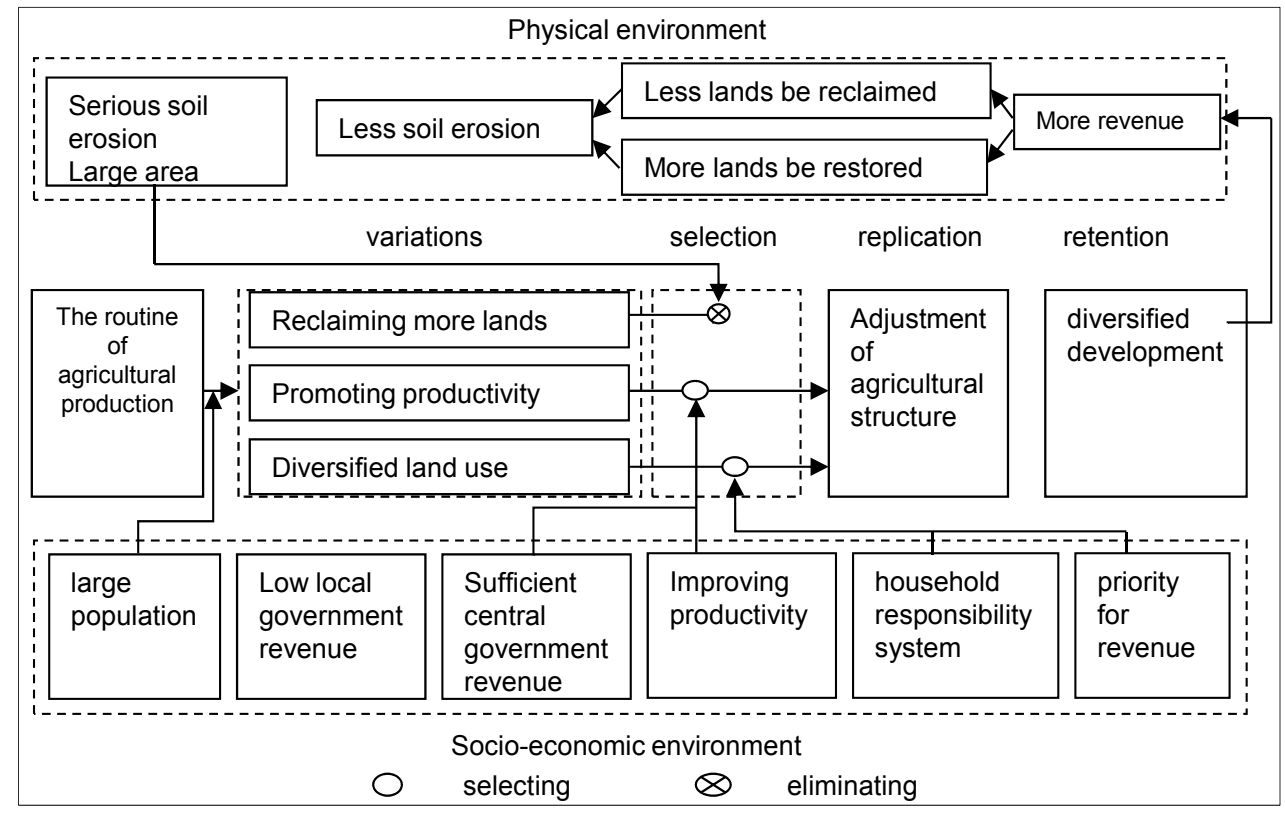

\subsubsection{Grain for Green Project}

Phase 3 has been in operation since the "Grain for Green project" policy was implemented in 1999. Until 1999, the physical environment improved but slowly; however, progress was made in some places. With the awareness of environmental protection enhancing, the central government implemented "Grain for Green" project to relieve the damages of physical environment and one large fund was founded for this project by the central government. In 1999, the local government started the "Grain for Green" project in Fuxian County funded by central government and $40 \%$ of restored lands were allowed to plant cash forest. According to local government, 240 yuan per ha every year can be got by peasants through transferring slope land to vegetation without any return. In this period, the population grew slowly and local government revenue increased rapidly but was still at a low level 
from about 1999 to 2010 (Figure 2a). The local government revenue was just 2485 ten thousand in 2000 (Table 3). Chinese economy kept growing rapidly during this time and central government revenue continued to increase greatly [80]. The productivity of agricultural production fluctuated at a relatively high level (Figure 2b). The grain total output dropped down since 1999 while no-grain percentage increased greatly (Figure 2c), which means "Grain for Green" took effect. It is further proved that the grain planting area, sown area for crops, cultivated land also dropped down since 1999 (Figure 2d).

Due to the awareness of environmental protection and strong support from the central government, facing serious water and soil loss on the Loess Plateau, "Grain for Green" was implemented to restore the damaged ecological environment and state-subsidized restoration development was selected (Figure 5). Due to relatively high productivity, food demand could be met when the "Grain for Green" project started [81,82]. "Grain for Green" had a positive effect on the physical environment in Fuxian County. According to the local government, until late 2010, the area of restored unsuitable land reached 15,773.33 ha. Serious soil erosion area in 2010 just covered $360.6 \mathrm{~km}^{2}, 8.62 \%$ of the whole county area. However, the routine depended on state subsidies. Once state subsidies were lessened or expired, the routine would be in trouble. Additionally, state subsidies didn't contribute to the fundamental solution of regional poverty. According to local peasants, it is found that they expected "Grain for Green project" policy continuing or they would consider reclaim if they have no other stable income.

Figure 5. The evolutionary framework of agricultural development transformation in phrase 3 .

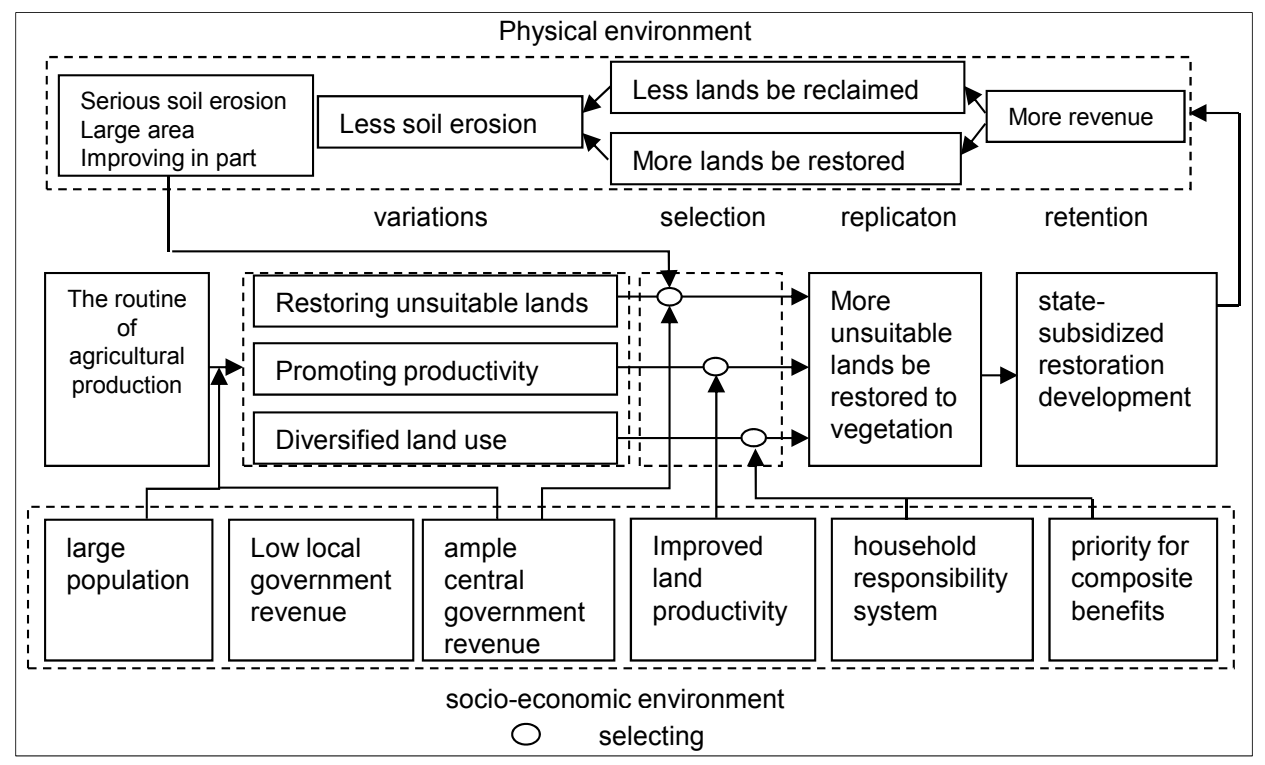

\subsubsection{Gully Land Consolidation Project}

Phrase 4 was in operation since the Gully Land Consolidation Project launched in 2011. Until late 2010, serious soil erosion area just covered $360.6 \mathrm{~km}^{2}, 8.62 \%$ of the whole county area according to data from local government. With "Grain for Green project" policy deadline approaching and state subsidies declining, Gully Land Consolidation Project was implemented to create more suitable land for more unsuitable land restoration to vegetation as well as promoting production conditions for 
agricultural scale operation. The Gully Land Consolidation Project was mainly funded by the central government and the local government also played a positive part this time. Land consolidation engineering, irrigation and drainage engineering, rural roads engineering, farmland protection and ecological environment conservation engineering, and other engineering were coordinated in this project. Large flat lands were formed obviously, which was important for modern agricultural development (Figure 6). Under the protection of the dam system, which is considered to be most effective way to conserve soil and water $[83,84]$, all the floods and flows could be filtered while abundant soil and natural fertilizer brought by floods and flows could be accumulated in front of the dams and in the fields. Dam lands in front of the dam will be gradually full of natural fertilizer, and fields will also be more fertile. At the same time, waters could be accumulated in front of key dams (see Figure 7). Some positive effects such as saving water, more farmland for food security, and reducing disasters have been recognized [37]. Nonetheless, more relational patterns should be developed in this routine due to its imperfections referred by Jin [38].

Figure 6. The comparison before and after land consolidation. Photos was taken in one of project regions in Niuwu town. (a) Sloping land before land consolidation; (b) large flat broad-base terraces after land consolidation; (c) river near-by land before land consolidation; (d) large flat river near-by land after land consolidation.

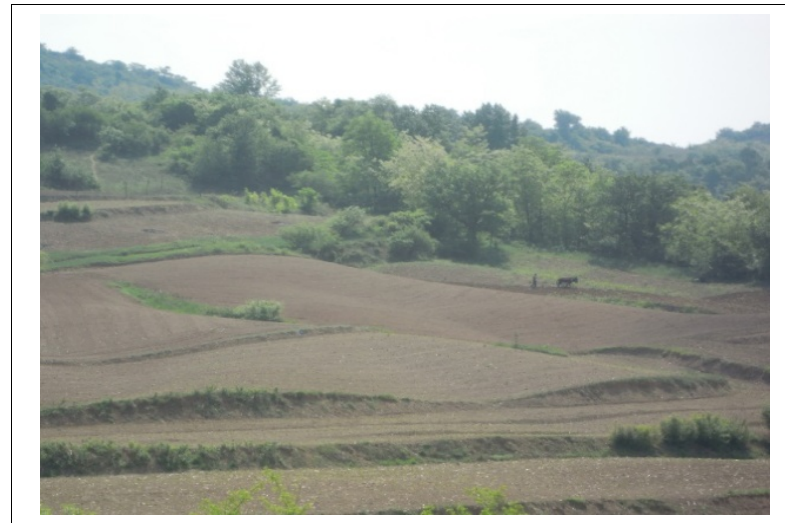

(a)

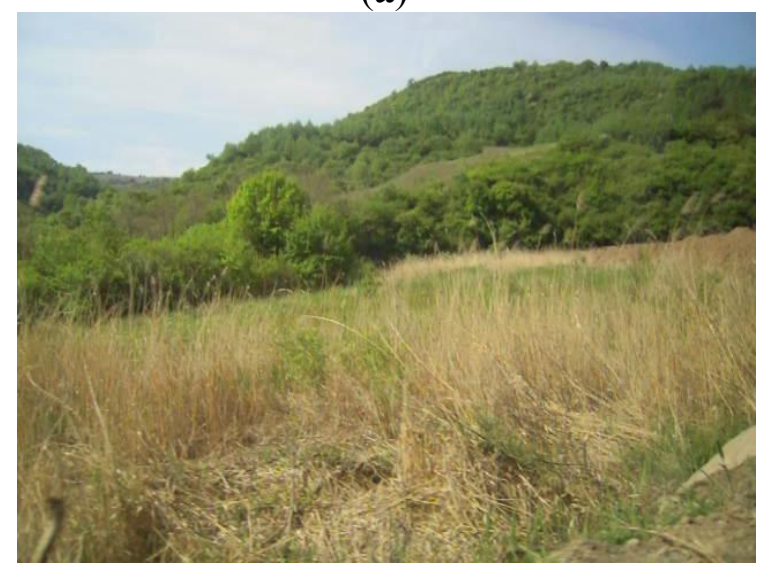

(c)

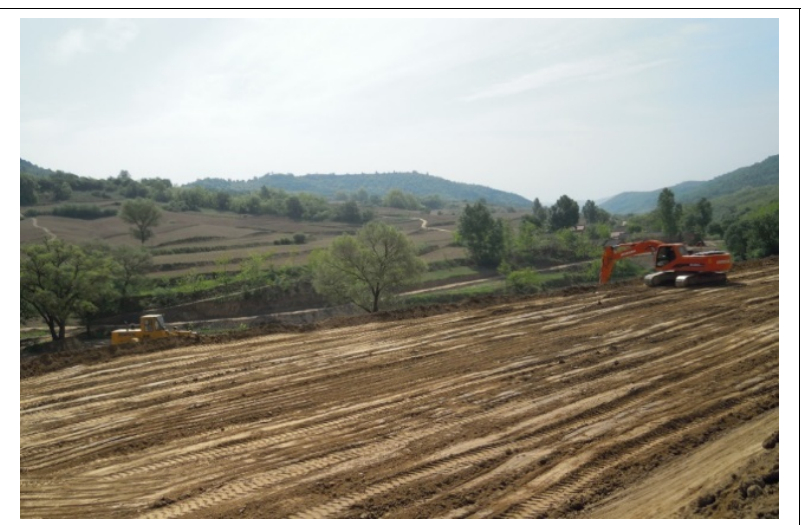

(b)

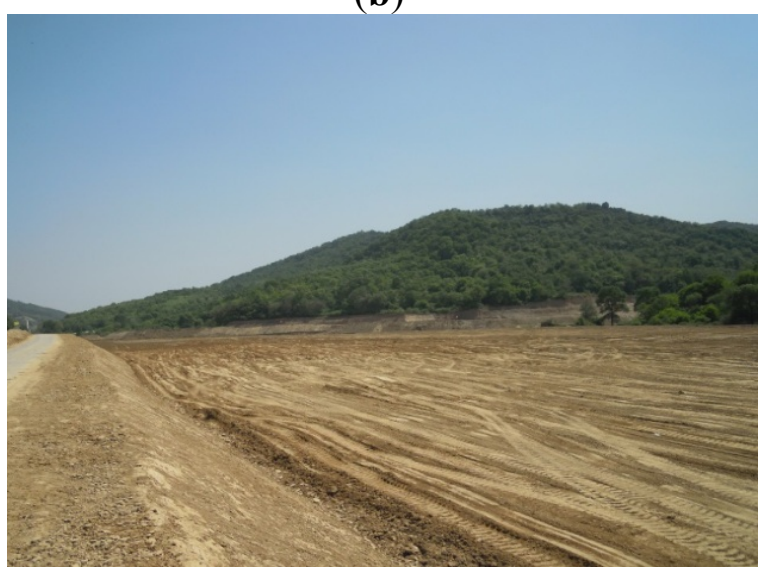

(d) 
Figure 7. The sketch map of the dam system with soil and water maintaining circle.

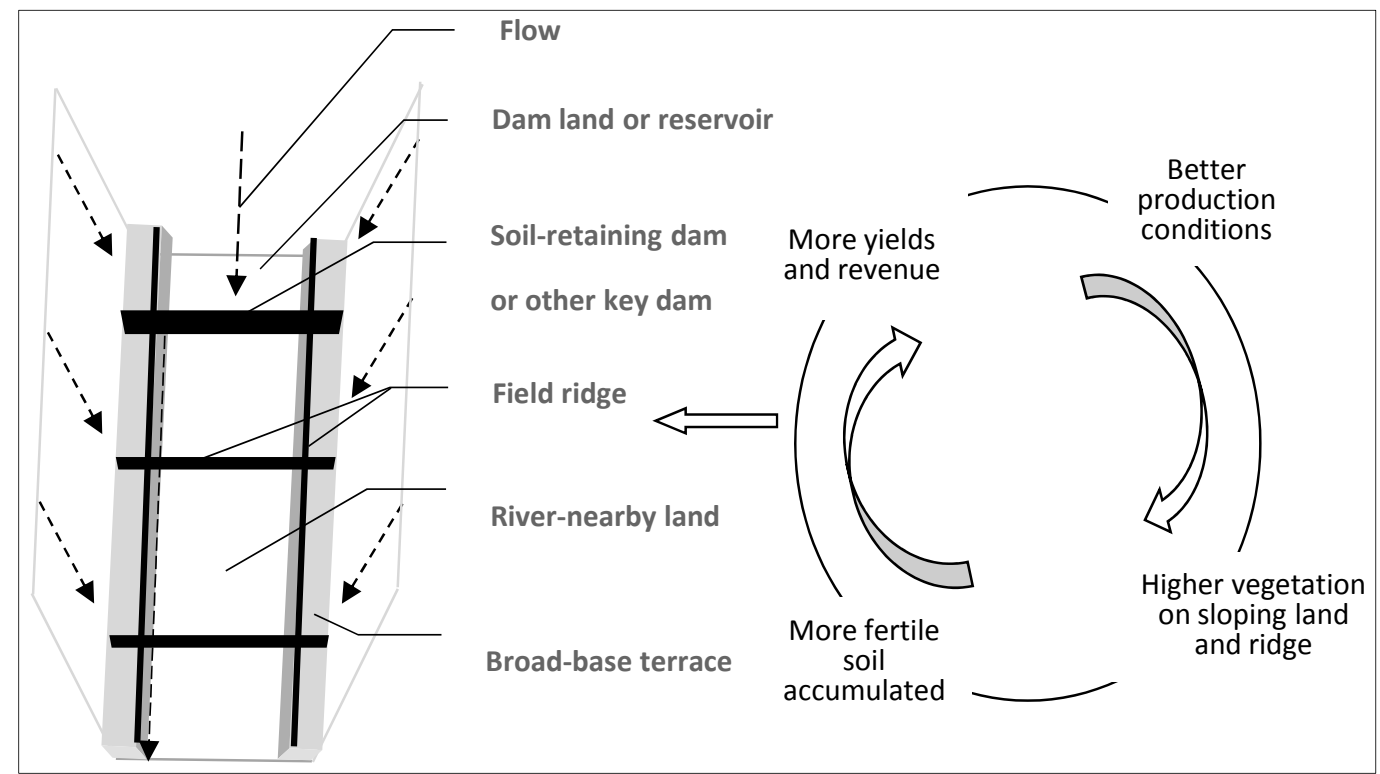

In sum, the Gully Land Consolidation Project gives a helpful way to balance agricultural development and environment protection (Figure 8). One hand, creating large flat lands and promoting production conditions could improve productivity greatly. River near-by lands (including dam land) are the most suitable type of cropping land $[85,86]$. In this project, creating dam land is priority. A virtuous circle, better conditions - more suitable land fully utilized — more steep land restored — less water and soil loss - better conditions, can be figured out. On the other hand, better conditions such as large flat land and accessible irrigation facilities would advance agricultural scale operation and other non-agricultural industries. With efficient agriculture developing gradually, peasants' income can be raised. Meanwhile, it is also good for raising local government revenue. So Gully Land Consolidation Project is also helpful to relieve regional poverty. Nonetheless, there are also several disadvantages for Gully Land Consolidation Project. One of them is the huge cost to conduct Gully Land Consolidation Project, about 120,000 yuan per ha (according to local government). Another problem is that Gully Land Consolidation Project should be protected by high vegetation coverage in project region. If not, Gully Land Consolidation Project could face the high risk of being destroyed due to floods caused by serious water and soil loss, especially when the extreme climate events come about frequently caused by climate changes. In other word, the emerging risk from the extreme climate events makes high standard construction of Gully Land Consolidation Project become so important and the high investment is necessary. High vegetation coverage in project region is important and reduces the risk of suffering the damages caused by floods [87]. Besides, not all the gullies were suitable to be reclaimed due to various gullies situations. Based on the better production conditions created by Gully Land Consolidation Project, one big pig farm in Niuwu town, named Fuxian Wangjiagou Modern Agriculture Demonstration Zone of Ecological Livestock-breeding, gave more attention to environment protection when it developed. This farm was established in 2012 and was designed in ecological thinking to prevent possible agricultural pollution (Figure 9). In the farm, pig manure from the pig breeding department was sent to organic fertilizer department and converted to organic fertilizer which was used in local fields or sold somewhere. All the wastes would be sent to organic 
fertilizer department. Early adoption of measures in ecological thinking to prevent contamination in the farm was one helpful exploration towards sustainable agriculture.

Figure 8. The evolutionary framework of agricultural development transformation in phrase 4 .

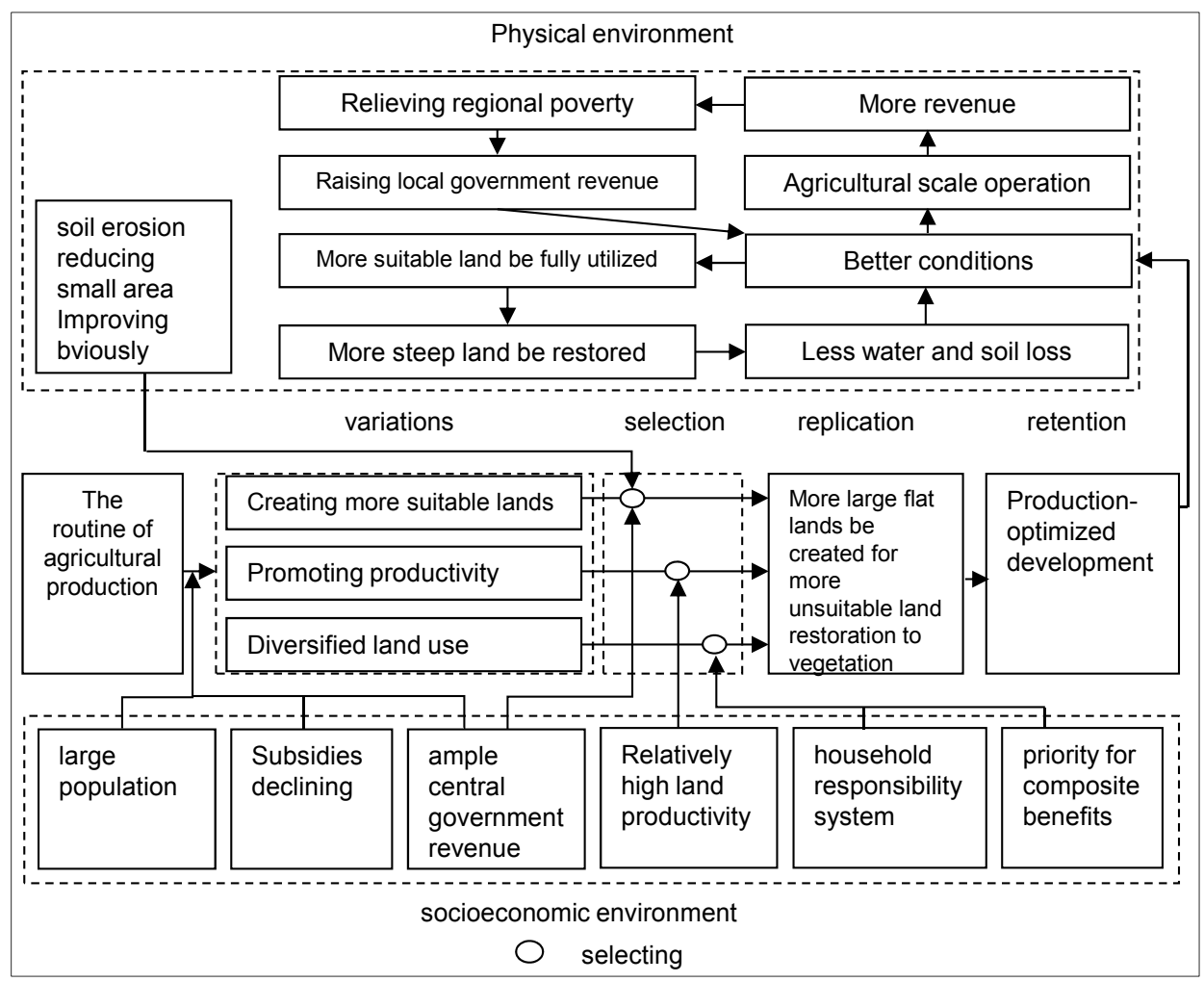

Figure 9. the ecological design of the pig farm.

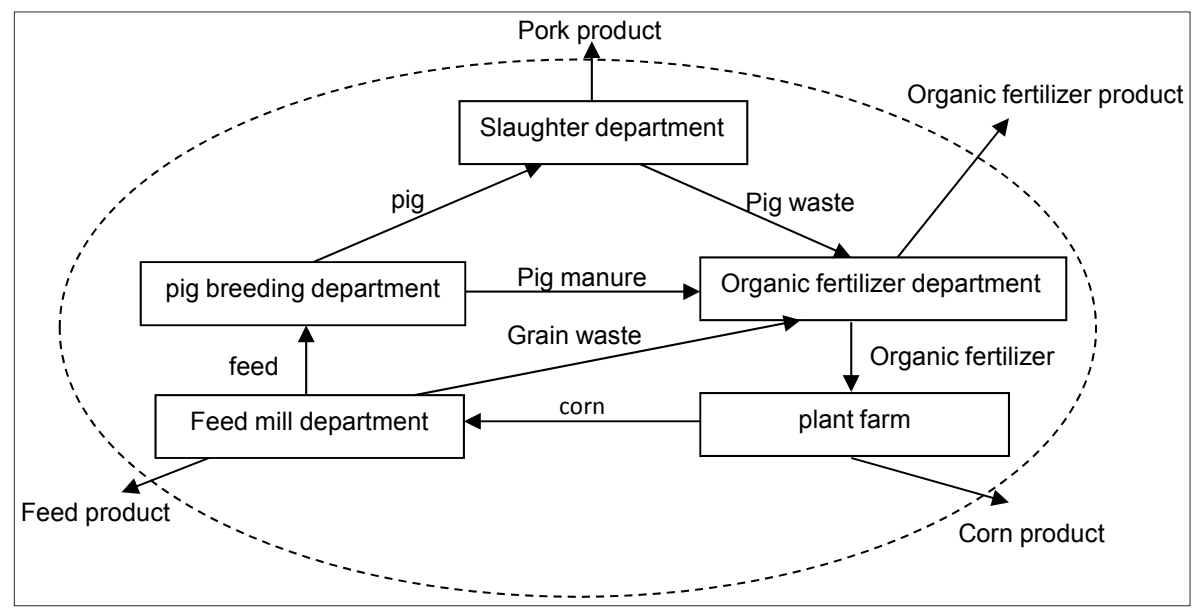

\subsection{The Possible Path for Agricultural Development Transformation towards One Efficient and} Sustainable Way in Fuxian County

4.2.1. The Possible Path from Serious Erosion Region to Region with More Sustainable Agriculture

In review of the evolutionary history of Fuxian County's agricultural development, one possible process can be recognized: mainly due to long irrational use, lots of serious soil erosion regions had 
been formed before the foundation of new China. Then, when the serious soil erosion regions' physical environment was greatly restored due to diversified land use and Grain for Green policy, serious soil erosion regions could be converted to regions with relatively good physical environment but poor production conditions. Under the protection of a relatively good physical environment, the Gully Land Consolidation Project could be constructed in the gullies. Through GLCP, some regions with poor production conditions could also be converted to production-optimized regions with good production conditions. After fully utilizing the good production conditions, agricultural scale operation could be advanced greatly. Thus, production-optimized regions could be converted to regions with developed agriculture when agriculture develops fully and is modernized greatly. Due to the experiences of the big pig farm named Fuxian Wangjiagou Modern Agriculture Demonstration Zone of Ecological Livestock-breeding, regions with developed agriculture could be converted to be regions with sustainable agriculture in ecological thinking when facing the agricultural pollution. Five types of regions could also be recognized in the process (Table 4). These types of regions may have a historical developing order: serious soil erosion regions $\rightarrow$ regions with poor production conditions $\rightarrow$ production-optimized regions $\rightarrow$ regions with developed agriculture $\rightarrow$ regions with sustainable agriculture. Serious soil erosion regions, regions with poor production conditions, production-optimized regions, and regions with developed agriculture are main types (Figure 10).

Table 4. The characteristics of five types of regions.

\begin{tabular}{lll}
\hline Region & Physical environment & Socioeconomic environment \\
\hline $\begin{array}{l}\text { serious soil erosion } \\
\text { regions }\end{array}$ & $\begin{array}{l}\text { serious soil erosion; } \\
\text { bad production conditions }\end{array}$ & $\begin{array}{l}\text { poverty; } \\
\text { low productivity; } \\
\text { monoculture development }\end{array}$ \\
\hline $\begin{array}{l}\text { regions with poor } \\
\text { production conditions }\end{array}$ & $\begin{array}{l}\text { soil erosion be improved; } \\
\text { bad production conditions }\end{array}$ & $\begin{array}{l}\text { poverty; } \\
\text { low productivity; } \\
\text { diversified development }\end{array}$ \\
\hline $\begin{array}{l}\text { production-optimized } \\
\text { regions }\end{array}$ & soil erosion be improved; & $\begin{array}{l}\text { poverty; } \\
\text { improving productivity; } \\
\text { diversified development }\end{array}$ \\
\hline $\begin{array}{l}\text { good production conditions } \\
\text { agriculture }\end{array}$ & soil erosion be improved; & $\begin{array}{l}\text { affluence; } \\
\text { high productivity; } \\
\text { agricultural modernization }\end{array}$ \\
\hline $\begin{array}{l}\text { good production conditions } \\
\text { agriculture }\end{array}$ & soil erosion be improved; & $\begin{array}{l}\text { affluence; } \\
\text { high productivity; }\end{array}$ \\
\hline
\end{tabular}


Figure 10. Description for four main types of regions existing in Fuxian County. (a) Photo 1 was taken in Jizixian town and shows serious soil erosion region with low vegetation coverage; (b) photo 2 was taken in Niuwu town and shows region with uneven and fragmented lands; (c) photo 3 was taken in Sixian town and shows region with good production conditions; (d) photos 4 was taken in Zhiluo town and shows an agricultural specialty farm for planting paddy as a kind of high-value crops there.



(a) Typical serious soil erosion region



(c) Typical production-optimized region

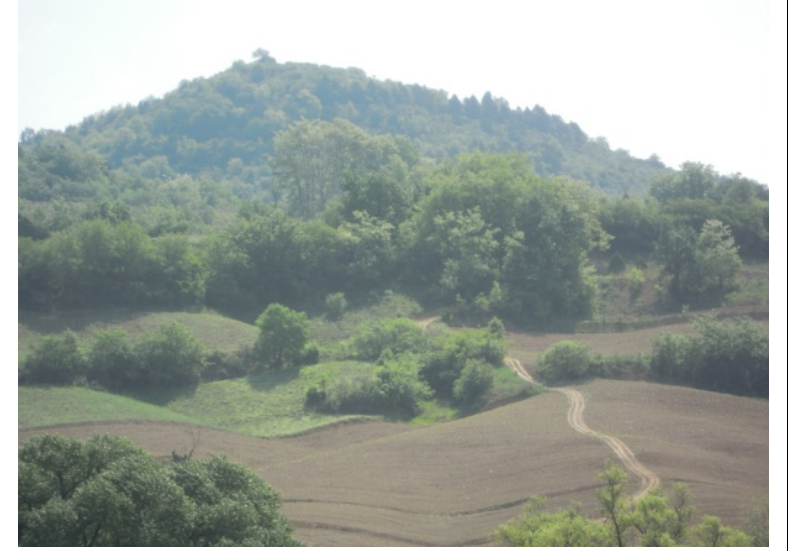

(b) Typical region with poor production conditions

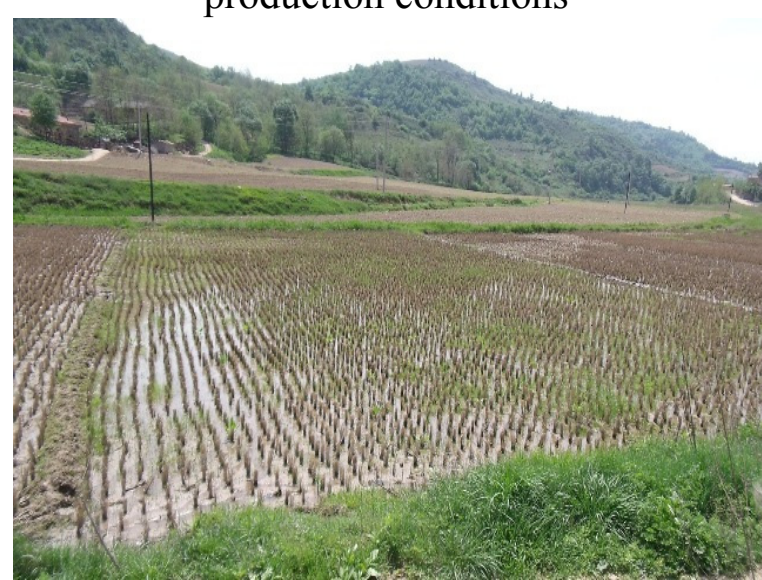

(d) Typical region with relatively developed agriculture

\subsubsection{How to Achieve an Efficient and Sustainable Routine?}

It is obvious that abundant practices of agricultural development contribute to the formation of a new efficient and sustainable routine. According to the possible path of agricultural development transformation in Fuxian County, the routine tends to be diversified and integrative, especially when there are various regional differences and a possible developing order. Diversified integrative development aims to construct a regional development towards sustainability (Figure 11). The possible path of agricultural development as well as five types of regions is included in the routine. Diversified integrative development offers one possible way to advance sustainable agriculture in a holistic perspective especially when facing differences in a region. Every region has its position in the developing order and different development strategy will be given. When it steps into upper position, new strategy will be given to it. Diversified integrative development is pluralistic. 
Figure 11. The structure of diversified integrative development towards an efficient and sustainable routine.

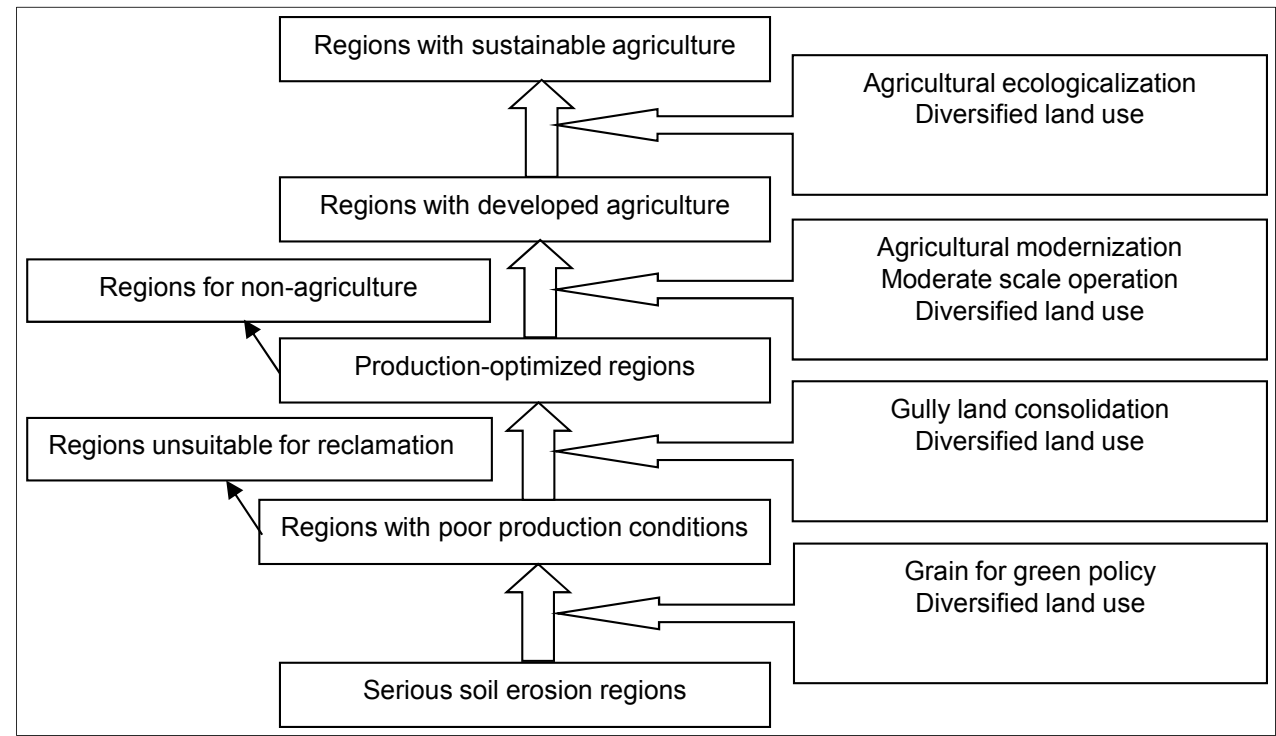

Serious soil erosion regions still cover a part of the county, $8.62 \%$ of the whole county area in 2010 . Serious soil erosion regions are usually barren and poor as mentioned above. The remediation of serious erosion regions costs much and is usually a non-profitable project. Thus, providing financial aid via state subsidies for "Grain for green" is priority, especially when Chinese central government revenue increases rapidly due to Chinese robust economy. For the local government, diversified land use for more revenue could be considered. The remediation of serious soil erosion regions funded by private capital and foreign investment could also be allowed according to the law and regulation. It is worth noting that the remediation of serious erosion regions is facing the important opportunity and will be improved high under the support of powerful state subsidies.

When physical environment is improved deeply, serious soil erosion regions could be converted to regions with poor production conditions which are still poor and lack of good production conditions. State-subsidized development can't solve the regional poverty, and, moreover, lands unsuitable for planting may be reclaimed again once subsidies are lowered or expired. So creating more suitable lands such as river-nearby lands and broad-base terrace is necessary. Gully land consolidation is selected. However, not all the gullies with poor production conditions should conduct "Gully Land Consolidation" project, in case that they would lead to new damages of physical environment. Thus, some gullies unsuitable for conducting "Gully Land Consolidation" project are kept as important conservation regions, which could be support by state subsidies continuously and develop other proper industries. Planting measures, engineering measures, and farming measures should be combined in “Gully Land Consolidation" project. Gully land consolidation costs much and can't be afforded by private in general. Thus, state subsidies are still necessary for production conditions optimization.

After production conditions optimization, lots of regions with poor production conditions are converted to production-optimized regions which are very suitable for agricultural development and bring important opportunities. Moderate scale operation, and diversified land use such as livestock industry and high-value cash crops need to be promoted for advancing agricultural modernization. Some of production-optimized regions can also be used for developing non-agricultural industries. 
When production-optimized regions complete the process of agricultural modernization based on good production conditions, they are converted to regions with developed agriculture. Regions with developed agriculture are usually rich. Problems, such as agricultural pollution, may emerge as one big challenge, which developed countries were ever confronted with. Thus, agricultural ecologicalization will be on the way in ecological thinking. When agricultural ecologicalization develops highly, regions with sustainable agriculture will be formed possibly.

\section{Conclusions}

This study has tried to develop a holistic "variation-selection-replication-retention" model to analyze the transformation of agricultural development from an evolutionary view. It is indicated that a variety of practices emerging in agricultural production will be selected by both physical and socioeconomic environment and best practices will be routinized usually by policies. Due to ever-changing environment changes, a routine is encouraged to make innovations and develop more relational patterns. It also implicates that a wise policy will be flexible and adaptive to various environmental changes and more innovations are encouraged for improvement. Thus, policies are not immutable and should be ready to adapt themselves to new environment changes. Policies are lively and vibrant organisms full of innovations.

In the case study of Fuxian County, it is suggested that diversified integrative development gives a possible way to realize more sustainable agriculture. Five types of regions are recognized in diversified integrative development: serious soil erosion regions, regions with poor production conditions, production-optimized regions, regions with developed agriculture, and regions with sustainable agriculture. Historical developing links are also revealed among them: serious soil erosion regions $\rightarrow$ regions with poor production conditions $\rightarrow$ production-optimized regions $\rightarrow$ regions with developed agriculture $\rightarrow$ regions with sustainable agriculture. Policy for diversified integrative development is pluralistic:

(a) For serious erosion regions, due to regional poverty and huge cost for restoration, state-subsidized "Grain for Green" is priory and deserves to be continued. Meanwhile, diversified land use for more revenue in "Grain for green" could be considered for local government. Private capital and foreign investment could also be considered according to the law and regulation.

(b) For regions with poor production conditions, under the protection of good physical environment, state-subsidized production optimization, "Gully Land Consolidation", ranks first consideration for promoting poor productions because the promotion of production conditions also cost much. Private capital and foreign investment could also be considered according to laws and regulations. Diversified land use for more revenue could also be considered for local government.

(c) For production-optimized regions, based on good production conditions, agricultural scale operation, and diversified land use such as livestock industry and high-value cash crops need to be promoted for advancing agricultural modernization. Advancing an agricultural scale operation is a priority for improving productivity and raising revenue. It is necessary to develop ago-industries for changing monoculture planting. 
(d) For regions with developed agriculture, agricultural ecologicalization should be advanced. Ecological thinking offers one possible sustainable way for modern agricultural production, no matter whether to prevent agricultural pollution or to deal with agricultural pollution damages.

\section{Acknowledgments}

This work was supported by the National Natural Science Foundation of China (Grant No.41130748; Grant No. 41201176; Grant No. 41101549). The authors also thank the Editors and referees for their helpful comments and suggestions.

\section{Author Contributions}

The authors shared equally in all sections of this paper. All the authors contributed to the research design. Yanjun Guo prepared the first draft. All the authors revised the manuscript, and approved the final one.

\section{Conflicts of Interest}

The authors declare no conflict of interest.

\section{References}

1. Wang, T.; Wu, J.; Kou, X. Ecologically asynchronous agricultural practice erodes sustainability of the Loess Plateau of China. Ecol. Appl. 2010, 20, 1126-1135.

2. Yang, W.; Yu, C. Regional Treatment and Evaluation in Loess Plateau; Science Press: Beijing, China, 1992. (in Chinese)

3. Lu, Z.; Liang, Y.; Liu, G. Ecological Agriculture in Loess Plateau, China; Shaanxi Science and Technology Press: Xi'an, China, 1997. (in Chinese)

4. Wu, Y.; Yang, W. Forest and Grassland Vegetation Construction and its Sustainable Development in Loess Plateau; Science Press: Beijing, China, 1998. (in Chinese)

5. Ritsema, C.J. Introduction: Soil erosion and participatory land use planning on the Loess Plateau in China. Catena 2003, 54, 1-5.

6. Fagerström, M.H.H.; Messing, I.; Wen, Z.M.; Trouwborst, K.O.; Xu, M.X.; Zang, X.P.; Olsson, C.; Andersson, C. A participatory approach for integrated conservation planning in a small catchment in Loess Plateau, China-Part II. Analysis and findings. Catena 2003, 54, 271-288.

7. Ostwald, M.; Chen, D. Land-use change: Impacts of climate variations and policies among small-scale farmers in the Loess Plateau, China. Land Use Policy 2006, 23, 361-371.

8. Nolan, S.; Unkovich, M.; Shen, Y.Y.; Li, L.L.; Bellotti, W. Farming systems of the Loess Plateau, Gansu Province, China. Agric. Ecosyst. Environ. 2008, 124, 13-23.

9. Fu, B.; Liu, Y.; Lü, Y.; He, C.; Zeng, Y.; Wu, B. Assessing the soil erosion control service of ecosystems change in the Loess Plateau of China. Ecol. Complexity 2011, 8, 284-293.

10. COSTLOP-CAS (Comprehensive Survey Team on Loess Plateau of Chinese Academy of Sciences). The Natural Environmental Characteristics and Evolvement; China Science and Technology Press: Beijing, China, 1991. (in Chinese) 
11. Wang, L.; Shao, M.A.; Wang, Q.; Gale, W.J. Historical changes in the environment of the Chinese Loess Plateau. Environ. Sci. Policy 2006, 9, 675-684.

12. Bettinger, R.L.; Barton, L.; Richerson, P.J.; Boyd, R.; Wang, H.; Choi, W. The transition to agriculture in northwestern China. Dev. Quat. Sci. 2007, 9, 83-101.

13. $\mathrm{Fu}, \mathrm{B}$. Soil erosion and its control in the loess plateau of China. Soil Use Manag. 1989, 5, 76-82.

14. Jiang, D. Soil Erosion and Control Models in the Loess Plateau; China Hydroelectricity Press: Beijing, China, 1997. (in Chinese)

15. Chen, C.K. The Discussion of Producing and Constructing for the Loess Plateau Policy Based on Developing Commercial Production. Acta Geogr. Sinica 1981, 36, 101-107. (in Chinese)

16. Liu, G. Soil conservation and sustainable agriculture on the Loess Plateau: Challenges and prospects. Ambio 1999, 28, 663-668.

17. Wu, H.I.; Childress, W.M.; Li, Y.; Spenced, R.D.; Ren, J.Z. An integrated simulation model for a semi-arid agroecosystem in the Loess Plateau of northwestern China. Agric. Syst. 1996, 52, 83-111.

18. Huang, M.; Shao, M.; Zhang, L.; Li, Y. Water use efficiency and sustainability of different long-term crop rotation systems in the Loess Plateau of China. Soil Tillage Res. 2003, 72, 95-104.

19. World Bank, ICR of Loess Plateau Watershed Rehabilitation Project. Available online: http://nweb90.worldbank.org/oed/oeddoclib.nsf/DocUNIDViewForJavaSearch/8525682E006860 3785256D17004305D0?OpenDocument (accessed on 27 June 2003).

20. Chen, S.J.; Wang, Y.; Wang, Y.J. The Loess Plateau Watershed Rehabilitation Project. In Proceedings of the Scaling up Poverty Reduction: A Global Learning Process and Conference, Shanghai, China, 25-27 May 2004.

21. Lei, D.; Shangguan, Z.P.; Li, R. Effects of the grain-for-green program on soil erosion in China. Int. J. Sediment Res. 2012, 27, 120-127.

22. Zhou, D.; Zhao, S.; Zhu, C. The Grain for Green Project induced land cover change in the Loess Plateau: A case study with Ansai County, Shanxi Province, China. Ecol. Indic. 2012, 23, 88-94.

23. Wang, J.J.; Jiang, Z.D.; Xia, Z.L. Grain-for-Green Policy and Its Achievements. In Restoration and Development of the Degraded Loess Plateau, China, 2nd ed.; Tsunekawa, A., Liu, G., Yamanaka, N., Du, S., Eds.; Springer: Tokyo, Japan, 2014; pp. 137-147.

24. Uchida, E.; Xu, J.; Xu, Z.; Scott, R. Are the poor benefiting from China's land conservation program? Environ. Dev. Econ. 2007, 4, 593-620.

25. Bennett, M.T. China's sloping land conversion program: Institutional innovation or business as usual? Ecol. Econ. 2008, 4, 699-711.

26. Liang, Y.; Li, S.; Feldman, M.W.; Daily, G.C. Does household composition matter? The impact of the Grain for Green Program on rural livelihoods in China. Ecol. Econ. 2012, 75, 152-160.

27. Shi, M.; Wang, T. An application of bio-economic household model to analysis on man-land relationship behavior in ecologically fragile land of China. Acta Geogr. Sinica 2005, 60, 165-174. (In Chinese)

28. Cao, S.; Xu, C.; Chen, L.; Wang, X. Attitudes of farmers in China's northern Shaanxi Province towards the land-use changes required under the Grain for Green Project, and implications for the project's success. Land Use Policy 2009, 26, 1182-1194. 
29. Liu, Z.; Li, B. Spatial and temporal changes in grain production before and after implementation of Grain for Green project in Loess Plateau region. Trans. Chin. Soc. Agric. Eng. 2012, 11, 1-8. (In Chinese)

30. Bullock, A.; King, B. Evaluating China's slope land conversion program as sustainable management in Tianquan and Wuqi Counties. J. Environ. Manag. 2011, 8, 1916-1922.

31. World Bank; ICR of Second Loess Plateau Watershed Rehabilitation Project. Available online: http://web.worldbank.org/external/projects/main?pagePK=104231\&piPK=73230\&theSitePK=409 41\&menuPK=228424\&Projectid=P056216 (accessed on 4 May 2014).

32. Scoones, I. Climate change and the challenge of non-equilibrium thinking. IDS Bull. 2004, 35, 11-15.

33. Tang, Q.; Bennett, S.J.; Xu, Y.; Li, Y. Agricultural practices and sustainable livelihoods: Rural transformation within the Loess Plateau, China. Appl. Geogr. 2013, 41, 15-23.

34. Zhao, X.Z.; Li, F.M.; Mo, F. Integrated conservation solutions for the endangered Loess Plateau of northwest China. Pak. J. Bot. 2012, 44, 77-83.

35. Chen, L.; Yang, L.; Wei, W.; Wang, Z.; Mo, B.; Cai, G. Towards sustainable integrated watershed ecosystem management: A case study in Dingxi on the Loess Plateau, China. Environ. Manag. 2013, 1, 126-137.

36. China Land and Resources News, revitalizing good Northern Shaanxi. 2012. Available online: http://special.gtzyb.com/121120/ (accessed on 4 March 2014). (In Chinese)

37. Liu, Q.; Wang, Y.; Zhang, J.; Chen, Y. Filling gullies to create farmland on the Loess Plateau. Environ. Sci. Technol. 2013, 14, 7589-7590.

38. Jin, Z. The creation of farmland by gully filling on the Loess Plateau: A double-edged sword. Environ. Sci. Technol. 2014, 2, 883-884.

39. Jiao, J. Countermeasures to Prevent Water Erosion in the Loess Plateau of China. In Restoration and Development of the Degraded Loess Plateau, China, 2nd ed.; Tsunekawa, A., Liu, G., Yamanaka, N., Du, S., Eds.; Springer: Tokyo, Japan, 2014; pp. 183-198.

40. Gruen, R.L.; Elliott, J.H.; Nolan, M.L. Sustainability science: An integrated approach for health-program planning. The Lancet 2008, 372, 1579-1589.

41. Jerneck, A.; Olsson, L.; Ness, B. Structuring sustainability science. Sustain. Sci. 2011, 6, 69-82.

42. Lang, D.J.; Wiek, A.; Bergmann, M. Transdisciplinary research in sustainability science: Practice, principles, and challenges. Sustain. Sci. 2012, 7, 25-43.

43. Mascarelli, A. Sustainability: Environmental puzzle solvers. Nature 2013, 494, 507-509.

44. Genus, A. Governing sustainability: A discourse-institutional approach. Sustainability 2014, 6, 283-305.

45. Douglass, G. Agricultural Sustainability in a Changing World Order; Westview Press: Boulder, CO, USA, 1984.

46. Schaller, N. The concept of agricultural sustainability. Agric. Ecosyst. Environ. 1993, 46, 89-97.

47. Ruttan, V.W. The transition to agricultural sustainability. Proc. Natl. Acad. Sci. USA 1999, 96, 5960-5967.

48. Pretty, J. Agricultural sustainability: Concepts, principles and evidence. Philos. Trans. R. Soc. B 2008, 363, 447-465.

49. Gómez-Limón, J.A.; Sanchez-Fernandez, G. Empirical evaluation of agricultural sustainability using composite indicators. Ecol. Econ. 2010, 69, 1062-1075. 
50. Hazell, P.; Wood, S. Drivers of change in global agriculture. Philos. Trans. R. Soc. B 2008, 363, 495-515.

51. Liu, G.; Tsunekawa, A.; Dang, X. Future Development-Related Challenges on the Loess Plateau. In Restoration and Development of the Degraded Loess Plateau, China, 2nd ed.; Tsunekawa, A., Liu, G., Yamanaka, N., Du, S., Eds.; Springer: Tokyo, Japan, 2014; pp. 267-282.

52. Lv, X.; Yu, X.; Fan, D. Estimation of non-point source pollution loads caused by soil erosion in China. J. Food Agric. Environ. 2012, 10, 1045-1050.

53. Liu, W.; Xing, M. Isotopic indicators of carbon and nitrogen cycles in river catchments during soil erosion in the arid Loess Plateau of China. Chem. Geol. 2012, 296, 66-72.

54. Ma, J.; Pan, F.; He, J. Petroleum pollution and evolution of water quality in the Malian River Basin of the Longdong Loess Plateau, Northwestern China. Environ. Earth Sci. 2012, 66, 1769-1782.

55. Hu, Y.; Wang, D.; Wei, L.; Sun, B. Heavy metal contamination of urban topsoils in a typical region of Loess Plateau, China. J. Soils Sediments 2014, 14, 928-935.

56. Li, Z.; Zheng, F.; Liu, W. Spatial distribution and temporal trends of extreme temperature and precipitation events on the Loess Plateau of China during 1961-2007. Quat. Int. 2010, 226, 92-100.

57. Li, Z.; Zheng, F.L.; Liu, W.Z. Spatially downscaling GCMs outputs to project changes in extreme precipitation and temperature events on the Loess Plateau of China during the 21st Century. Glob. Planet. Change 2012, 82, 65-73.

58. Wan, L.; Zhang, X.P.; Ma, Q.; Zhang, J.J.; Ma, T.Y.; Sun, Y.P. Spatiotemporal characteristics of precipitation and extreme events on the Loess Plateau of China between 1957 and 2009. Available online: http://onlinelibrary.wiley.com/doi/10.1002/hyp.9951/pdf (accessed on 21 August 2013).

59. Nelson, R.R.; Winter, S.G. An Evolutionary Theory of Economic Change; Harvard Business School Press: Cambridge, UK, 1982.

60. Hammerstein, P.; Hagen, E.H. The second wave of evolutionary economics in biology. Trends Ecol. Evol. 2005, 20, 604-609.

61. Ruth, M. Evolutionary economics at the crossroads of biology and physics. J. Soc. Evol. Syst. 1996, 19, 125-144.

62. Powell, J.H.; Wakeley, T.M. Evolutionary concepts and business economics: Towards a normative approach. J. Bus. Res. 2003, 56, 153-161.

63. Nelson, R.R. Economic development from the perspective of evolutionary economic theory. Oxford Dev. Stud. 2008, 1, 9-21.

64. Foxon, T.J. Responding to the financial crisis: Need for a new economics. Environ. Innov. Soc. Transform. 2013, 6, 126-128.

65. Foster, J.; Metcalfe, J.S. Economic emergence: An evolutionary economic perspective. J. Econ. Behav. Org. 2012, 82, 420-432.

66. Safarzyńska, K.; Frenken, K.; van den Bergh, J.C. Evolutionary theorizing and modeling of sustainability transformations. Res. Policy 2012, 41, 1011-1024.

67. Foster, J. The analytical foundations of evolutionary economics: From biological analogy to economic self-organization. Struct. Change Econ. Dyn.1997, 8, 427-451.

68. Gowdy, J. Avoiding self-organized extinction: Toward a co-evolutionary economics of sustainability. Int. J. Sustain. Dev. World Ecol. 2007, 1, 27-36. 
69. Nill, J.; Kemp, R. Evolutionary approaches for sustainable innovation policies: From niche to paradigm? Res. Policy 2009, 38, 668-680.

70. Kogut, B.; Zander, U. Knowledge of the firm and the evolutionary theory of the multinational corporation. J. Int. Bus. Stud. 1993, 24, 625-645.

71. Zollo, M.; Winter, S.G. Deliberate learning and the evolution of dynamic capabilities. Org. Sci. 2002, 13, 339-351.

72. Brennan, R. Evolutionary economics and the markets-as-networks approach. Ind. Mark. Manag. 2006, 35, 829-838.

73. Becker, M.; Lazaric, N.; Nelson, R.R.; Winter, S.G. Applying organizational routines in understanding organizational change. Ind. Corp. Change 2005, 14, 775-791.

74. Liu, J.; Chen, J.; Fang, S.; Li, Q. Chinese agricultural policies in thirty years and analysis on the effects. China Popul. Resour. Environ. 2008, 18, 1-6.

75. Douglas, H.R. American and Chinese Agricultural Policy since 1949: An Overview. Procedia-Soc. Behav. Sci. 2010, 2, 6692-6701.

76. Hatani, F.; McGaughey, S.L. Network cohesion in global expansion: An evolutionary view. J. World Bus. 2013, 4, 455-465.

77. Zhao, Y.T.; Chang, Q.R.; Li, C.P.; Zhang, Y.G. Study on the Spatial Variability and Distribution Pattern of Soil Available Nutrients in Gully Loess Plateau Farmland: Shaanxi Fuxian as an Example. Chin. J. Soil Sci. 2012, 43, 1438-1443. (In Chinese)

78. The Local Records Compile Committee of Fuxian County. Local chronicles of Fuxian County; Shaanxi People's Publishing House Press: Xi'an, China, 1994. (In Chinese)

79. Sachs, J.D.; Woo, W.T. Understanding China's economic performance. J. Policy Reform 2001, 1, $1-50$.

80. Yao, Y. The Chinese growth miracle. Handbook Econ. Growth 2014, 2, 943-1031.

81. Feng, Z.; Yang, Y.; Zhang, Y.; Zhang, P.; Li, Y. Grain-for-green policy and its impacts on grain supply in West China. Land Use Policy 2005, 22, 301-312.

82. Xu, Z.; Xu, J.; Deng, X.; Huang, J.; Uchida, E.; Rozelle, S. Grain for green versus grain: Conflict between food security and conservation set-aside in China. World Dev.2006, 34, 130-148.

83. Xu, X.; Zhong, H.; Zhong, O. Development of check-damsystems in gullies on the Loess Plateau, China. Environ. Sci. Policy 2004, 7, 79-86

84. Ran, D.; Luo, Q.; Liu, B. Effect of check-dams on flood and sediment reduction in middle reaches of Yellow River. J. Hydraul. Eng. 2004, 5, 7-13. (In Chinese)

85. Liu, Y.H. Land Type and Their Assessment on the Loess Plateau of Northern Shaanxi Province. Acta Geogr. Sinica 1985, 40, 121-129. (In Chinese)

86. Li, Z.; Cai, G.; Zeng, G. Simulation on relations between land use type and land productivity in Loess Hilly Region: A case study in Wangjiagou catchment. Scientia Geogr. Sinica 2007, 27, 53-57.

87. Li, Z.; Liu, W.; Zhang, X.; Zheng, F. Impacts of land use change and climate variability on hydrology in an agricultural catchment on the Loess Plateau of China. J. Hydrol. 2009, 377, 35-42.

(C) 2014 by the authors; licensee MDPI, Basel, Switzerland. This article is an open access article distributed under the terms and conditions of the Creative Commons Attribution license (http://creativecommons.org/licenses/by/3.0/). 